\title{
Slaughter yield and fatty acid profiles of fillets of pike (Esox lucius L.) caught before and after spawning
}

\author{
Zdzisław Zakęś, Renata Pietrzak-Fiećko, Mirosław Szczepkowski, \\ Monika Modzelewska-Kapituła, Barbara Jankowska
}

Received - 10 November 2015/Accepted - 07 December 2015. Published online: 31 December 2015; Inland Fisheries Institute in Olsztyn, Poland Citation: Zakęś Z., Pietrzak-Fiećko R., Szczepkowski M., Modzelewska-Kapituła M., Jankowska B. 2015 - Slaughter yield and fatty acid profiles of fillets of pike (Esox lucius L.) caught before and after spawning - Arch. Pol. Fish. 23: 231-235.

\begin{abstract}
The aim of the study was to determine the impact pike fishing season (before spawning in fall (group A) and after spawning in spring (group B)) had on the slaughter yield and fillet fatty acid profile. The slaughter yield of fillets with skin and skinned fillets from the group B fish was significantly lower (by approximately $7.5 \%$ of body weight). The fatty acid profile of the fish meat from the groups examined differed significantly. The fillets of pike caught before spawning were dominated by unsaturated fatty acids (UFA), while those from fish caught after spawning had mainly saturated fatty acids
\end{abstract}

\section{Z. Zakęś [ [”]}

Department of Aquaculture

Inland Fisheries Institute in Olsztyn,

Oczapowskiego 10, 10-719 Olsztyn, Poland

Tel.: +48 89 5240171, e-mail: z.zakes@infish.com.pl

\section{R. Pietrzak-Fiećko}

Department of Commodities and Food Analysis,

Faculty of Food Sciences,

University of Warmia and Mazury in Olsztyn, Poland

\section{Szczepkowski}

Department of Sturgeon Fish Breeding,

Inland Fisheries Institute in Olsztyn, Poland

\section{Modzelewska-Kapituła}

Department of Industrial Commodity, Basics of Techniques and Energy Management, Faculty of Food Sciences,

University of Warmia and Mazury in Olsztyn, Poland

\section{B. Jankowska}

Department of Meat Technology and Chemistry, Faculty of Food Sciences, University of Warmia and Mazury in Olsztyn, Poland
(SFA). The share of polyunsaturated fatty acids (PUFA) in the fillets of fish that had spawned was sixfold lower, and the $n-3$ PUFA differences were nearly ninefold. The content of eicosapentaenoic (EPA) and docosahexaenoic (DHA) fatty acids in fillets of fish that had spawned was ninefold lower than in those that had not yet done so. Consequently, the ratio of n-3 PUFA/n-6 PUFA in pike from group A was over three times higher than that in the fish that had spawned (2.61 vs 0.82). Fillets from pike that have spawned are a significantly poorer source of valuable fatty acids for consumers.

Keywords: utility traits, filet nutritional quality, fishing season

The utility traits of fish, for example slaughter yield or nutritional parameters, are specific to species, and within taxa these depend on environmental conditions (primarily diet), size/age, and fishing season (see Jobling 2001, Shirai et al. 2002). The impact of diet on the values of these traits has been documented widely, and is particularly evident when substituting high energy compound diets for natural food. This effect is observed in freshwater predatory fish including pike, Esox lucius L. (i.e., Jankowska et al. 2008). The nutritional value of fillets, mainly the fat content and the fatty acid profiles, can fluctuate annually and is determined by generative growth, among other factors (Luzzana et al. 1996, Sushchik et al. 2007). The fatty acid profiles of fish caught after spawning can differ substantially from those of fish

\footnotetext{
C Copyright by Stanisław Sakowicz Inland Fisheries Institute in Olsztyn.

(c) 2015 Author(s). This is an open access article licensed under the Creative Commons Attribution-NonCommercial-NoDerivs License (http://creativecommons.org/licenses/by-nc-nd/3.0/).
} 
caught at other times of year and are strictly linked with the cycle of gametogenesis (i.e., Shirai et al. 2001).

One active form of fish conservation is restocking. Often the production of stocking material is preceded by catching spawners in open waters during their natural spawning periods. During the closed fishing season in Poland, most pike spawners are caught in the Mazury region (northeast Poland) and this species comprises about $75 \%$ of all fish caught during this period (Z. Zakęś, unpublished data). After stripping the spawners of their eggs and milt, they are usually sold at market as fish for consumption. Because the utility traits of fish can be determined by the season in which they are caught, it was justified to conduct this study the aim of which was to compare the slaughter yield and fillet fatty acid profiles of pike caught before and after spawning.

The pike were caught using fishing gear in Lake Dgał Wielki (Mazurian Lake District, northeast Poland). Two samples of fish were caught - the first in fall (November - group A) and the second in spring (April - group B). Ten specimens were obtained per group, and the male to female ratio was $1: 1$. The specimens were of similar weight at approximately $0.5 \mathrm{~kg}$ and total length at $41 \mathrm{~cm}$ (Table 1). The fish were gutted, headed with a simple cut, and filleted, and then the fillets were skinned. At each stage of processing-that is gutted fish, gutted and headed fish, fillet with skin, and skinned fillet-the relative percentage share of the whole fish weight (BW) was determined. The weight of the fish and subsequent body parts was determined to $\pm 0.1 \mathrm{~g}$.

The skinned pike fillets were ground through $3 \mathrm{~mm}$ mesh, and this was the material used for analyzing the contents of basic components and for the analysis of fatty acid profiles. Two fillets from each specimen were ground and analyzed together (for each fish group $n=10$ ). The analysis of the fatty acid composition of skinned pike fillets was done after the muscle lipids were cold extracted according to the method by Folch et al. (1957). The fatty acids were methylated with a mixture of chloroform:methanol:sulfuric acid (100:100:1) (Peisker 1964). Chromatographic separation was performed on a Agilent Technologies (USA) 6890N gas chromatograph with a flame-ionization detector (FID), a capillary column of $30 \mathrm{~m}$ with an internal diameter of $0.32 \mathrm{~mm}$. The liquid phase was Supelcowax 10 with a film thickness of $0.25 \mathrm{~mm}$. The operating conditions were as follows: helium carrier gas flow of $1 \mathrm{ml} \mathrm{min}^{-1}$; detector temperature of $250^{\circ} \mathrm{C}$; injector $225^{\circ} \mathrm{C}$; column $180^{\circ} \mathrm{C}$. The detector signals were recorded with a Philips recorder on a scale of $1 \mathrm{mV}$ at a belt speed of $10 \mathrm{~mm} \mathrm{~min}{ }^{-1}$. The identification of each fatty acid was done by comparing the retention times of standards from Supelco (Bellefonte PA, USA).

The normality of the data distribution and the homogeneity of variance was verified with standard statistical procedures (Statistica 6.0 PL, StatSoft Inc., Tulsa, OK, USA). One-way analysis of variance (ANOVA) was used to compare means. If significant

Table 1

Slaughter yield of pike (E. lucius) caught in the fall before spawning (group A) and in the spring after spawning (group B) (\% body weight (BW)) (mean values \pm SEM)

\begin{tabular}{lll}
\hline \hline Parameters & Group A (n=10) & Group B (n=10) \\
\hline \hline Body weight (BW; g) & $569.5 \pm 42.2$ & $443.0 \pm 32.5$ \\
Slaughter yield & & \\
Gutted fish (\% BW) & $89.6 \pm 0.9$ & $92.3 \pm 0.8$ \\
Gutted and headed fish (\% BW) & $69.2 \pm 0.7$ & $67.7 \pm 0.8$ \\
Fillet with skin (\% BW) & $61.7^{\mathrm{a}} \pm 0.8$ & $54.2^{\mathrm{b}} \pm 0.6$ \\
Skinned fillet (\% BW) & $52.9^{\mathrm{a}} \pm 5.3$ & $45.4^{\mathrm{b}} \pm 0.7$ \\
Loss (\% BW) & $0.7^{\mathrm{a}} \pm 0.1$ & $2.3^{\mathrm{b}} \pm 0.1$ \\
\hline \hline
\end{tabular}

Mean values in the same row with different letter indexes differ significantly statistically at a level of significance of $\mathrm{P} \leq 0.01$ 
differences were noted among fish groups $(\mathrm{P} \leq 0.01)$, further statistical analysis was performed using Duncan's test. All values are expressed in percentages, and before statistical analyses they were transformed with the arcsin function.

The slaughter yield of fish is more advantageous than that of terrestrial animals and ranges from $30-40 \%$ BW among Siluriformes to 50-65\% BW among Salmoniformes (Jobling 2001). Freshwater predatory fish such as pike or pikeperch (Sander lucioperca (L.)) fall within this range as the skinned fillet comprises approximately 50\% BW (Jankowska et al. 2003). Similar results were obtained in the present study; the slaughter yield of the fillet with skin and the skinned fillet obtained in fall before spawning was significantly higher than that obtained after spawning. The mean difference was $7.5 \% \mathrm{BW}$ $(\mathrm{P}<0.01$; Table 1). The muscle mass of pike after spawning was significantly lower, which might be connected with energy expenditures during spawning migrations and the act of spawning itself. Additionally, it was more difficult to process, and losses in groups A and B were 0.7 and 2.3\% BW, respectively, which meant that the slaughter yield of fish that had spawned was also lower, especially with regard to the fillets (Table 1).
The fatty acid content of the meat from pike before and after spawning differed diametrically (Tables 2 and 3). This referred to both groups of fatty acids and to particular acids. The contents of saturated fatty acids (SFA) and unsaturated fatty acids (UFA) was different. UFA dominated in the fillets from the group of fish caught before spawning, while in fish that had spawned the dominant group was SFA, which comprised as much as $64.71 \%$ of total fatty acids (tFA; Table 2). Fillets of fish from group B were richer in monounsaturated fatty acids (MUFA), while the share of polyunsaturated fatty acids (PUFA) in the fillets of pike that had spawned was as much as sixfold lower than in the fish that had not spawned (10.67 vs $58.33 \%$ tFA). The level of $n-3$ PUFA in pike from group $B$ was nearly ninefold lower (4.84 vs $41.26 \%$ tFA). The content of n-6 PUFA in groups $\mathrm{A}$ and $\mathrm{B}$ was 15.79 and $5.84 \% \mathrm{tFA}$, respectively (Table 2). Consequently, the $n-3 / n-6$ ratio in pike from group A was more than threefold higher than in the fish that had spawned (2.61 vs 0.82 ).

Significant differences were confirmed among groups with regard to most of the fatty acids analyzed (Table 3). Particularly significant differences were noted with regard to eicosapentaenoic acid (EPA; 20:5 n-3) and docosahexaenoic acid (DHA;

Table 2

Fatty acid profiles (\% of total fatty acids) in fillets of pike (E. lucius) caught in fall before spawning (group A) and in spring after spawning (group B) (mean values \pm SEM)

\begin{tabular}{lll}
\hline \hline Fatty acids & Group A $(\mathrm{n}=10)$ & Group B $(\mathrm{n}=10)$ \\
\hline \hline SFA $^{1}$ & $25.70^{\mathrm{a}} \pm 1.07$ & $64.71^{\mathrm{b}} \pm 2.02$ \\
$\mathrm{UFA}^{2}$ & $74.30^{\mathrm{a}} \pm 1.07$ & $35.29^{\mathrm{b}} \pm 2.01$ \\
MUFA $^{3}$ & $15.97^{\mathrm{a}} \pm 0.56$ & $24.61^{\mathrm{b}} \pm 0.88$ \\
PUFA $^{4}$ & $58.33^{\mathrm{a}} \pm 1.62$ & $10.67^{\mathrm{b}} \pm 2.73$ \\
n-3 PUFA $^{5}$ & $41.26^{\mathrm{a}} \pm 1.36$ & $4.84^{\mathrm{b}} \pm 1.79$ \\
n-6 PUFA & $15.79^{\mathrm{a}} \pm 0.44$ & $5.84^{\mathrm{b}} \pm 0.99$ \\
n-3 PUFA/n-6 PUFA & $2.61^{\mathrm{a}} \pm 0.13$ & $0.82^{\mathrm{b}} \pm 0.19$ \\
\hline \hline
\end{tabular}

Mean values in the same row with different letter indexes differ significantly statistically at a level of significance of $\mathrm{P} \leq 0.01$

${ }^{1}$ SFA - saturated fatty acids: $\Sigma$ 14:0, 15:0, 16:0, 18:0, 20:0;

${ }^{2}$ UFA - unsaturated fatty acids: $\Sigma 14: 1,16: 1,17: 1,18: 1$ cis9, 18:1cis11, 18:2n-6, 18:3n-3, 18:4, 20:1n-9, 20:1n-7, 20:2, 20:3n-6, 20:4n-6, 20:4n-3, 20:5n-3, 22:5n-6, 22:5n-3, 22:6n-3;

${ }^{3}$ MUFA - monounsaturated fatty acids: $\Sigma$ 14:1, 16:1, 17:1, 18:1cis9, 18:1cis11, 20:1n-9, 20:1n-7;

${ }^{4}$ PUFA - polyunsaturated fatty acids: $\Sigma$ 18:2n-6, 18:3n-3, 18:4, 20:2, 20:3n-6, 20:4n-6, 20:4n-3, 20:5n-3, 22:5n-6, 22:5n-3, 22:6n-3;

${ }^{5}$ n-3 PUFA - PUFA from the n-3 family: $\Sigma$ 18:3n-3, 20:4n-3, 20:5n-3, 22:5n-3, 22:6n-3;

${ }^{6}$ n-6 PUFA - PUFA from the n-6 family: $\Sigma$ 18:2n-6, 20:3n-6, 20:4n-6, 22:5n-6. 
Table 3

Content of individual fatty acids in fillets of pike (E. lucius) caught in fall before spawning (group A) and in spring after spawning (group B) (\% of total fatty acids) (mean values \pm SEM)

\begin{tabular}{lll}
\hline \hline Fatty acids & Group A $(\mathrm{n}=10)$ & Group B $(\mathrm{n}=10)$ \\
\hline $14: 0$ & $1.02^{\mathrm{a}} \pm 0.06$ & $2.78^{\mathrm{b}} \pm 0.10$ \\
$14: 1$ & $0.14^{\mathrm{a}} \pm 0.02$ & $0.07^{\mathrm{b}} \pm 0.01$ \\
$15: 0$ & $0.35^{\mathrm{a}} \pm 0.02$ & $1.15^{\mathrm{b}} \pm 0.06$ \\
$16: 0$ & $18.72^{\mathrm{a}} \pm 0.92$ & $44.29^{\mathrm{b}} \pm 1.49$ \\
$16: 1$ & $3.69^{\mathrm{a}} \pm 0.15$ & $4.64^{\mathrm{b}} \pm 0.21$ \\
$17: 1$ & $0.48^{\mathrm{a}} \pm 0.05$ & $0.89^{\mathrm{b}} \pm 0.06$ \\
$18: 0$ & $5.60^{\mathrm{a}} \pm 0.21$ & $14.51^{\mathrm{b}} \pm 0.51$ \\
$18: 1$ cis9 & $8.62^{\mathrm{a}} \pm 0.37$ & $12.60^{\mathrm{b}} \pm 0.50$ \\
$18: 1$ cis 11 & $2.68^{\mathrm{a}} \pm 0.06$ & $5.12^{\mathrm{b}} \pm 0.29$ \\
$18: 2 \mathrm{n}-6$ & $4.90^{\mathrm{a}} \pm 0.38$ & $2.87^{\mathrm{b}} \pm 0.37$ \\
$18: 3 \mathrm{n}-3$ & $3.01^{\mathrm{a}} \pm 0.52$ & $0.55^{\mathrm{b}} \pm 0.11$ \\
$18: 4$ & $0.63 \pm 0.05$ & $n . d$. \\
$20: 0$ & $n \cdot d$. & $0.21 \pm 0.01$ \\
$20: 1 \mathrm{n}-9$ & $n \cdot d$. & $1.30 \pm 0.12$ \\
$20: 1 \mathrm{n}-7$ & $0.37 \pm 0.07$ & $n . d$. \\
$20: 2$ & $0.65 \pm 0.07$ & $n . d$. \\
$20: 3 \mathrm{n}-6$ & $n \cdot d$. & $0.02 \pm 0.02$ \\
$20: 4 \mathrm{n}-6$ & $8.60^{\mathrm{a}} \pm 0.22$ & $1.78^{\mathrm{b}} \pm 0.52$ \\
$20: 4 \mathrm{n}-3$ & $0.62^{\mathrm{a}} \pm 0.06$ & $0.02^{\mathrm{b}} \pm 0.02$ \\
$20: 5 \mathrm{n}-3$ & $6.67^{\mathrm{a}} \pm 0.22$ & $0.73^{\mathrm{b}} \pm 0.30$ \\
$22: 5 \mathrm{n}-6$ & $2.29^{\mathrm{a}} \pm 0.11$ & $0.31^{\mathrm{b}} \pm 0.12$ \\
$22: 5 \mathrm{n}-3$ & $3.00^{\mathrm{a}} \pm 0.15$ & $0.36^{\mathrm{b}} \pm 0.14$ \\
$22: 6 \mathrm{n}-3$ & $27.96^{\mathrm{a}} \pm 1.43$ & $3.13^{\mathrm{b}} \pm 1.25$ \\
\hline \hline
\end{tabular}

Mean values in the same row with different letter indexes differ significantly statistically at a level of significance of $\mathrm{P} \leq 0.01$, n.d. not dected

20:6 n-3), the contents of which in the fillets of fish that had spawned was ninefold lower than in the fillets of fish from group A (Table 3). Schwalme et al. (1993) analyzed the annual cycle of fatty acid profiles of female pike, and they also noted significant decreases in the contents of DHA in the fillets of this species in the months following spawning, i.e., in March and April. The observations of these authors correspond to those of the present study. The muscles are a kind of PUFA reservoir in fish, and these reserves are shifted to the gonads in the pre-spawning period (Luzzana et al. 1996, Sushchik 2007). In the present study, we analyzed males and females together in the different groups. It has been shown that in both vitellogenesis and spermatogenesis PUFA retained in the liver and muscles shifts to the gonads, and in the case of muscles this is especially effective for DHA (Luzzana et al. 1996). It was decided to concentrate on the fillets in the present study since this is the primary part of the pike body that is used in the human diet.

In conclusion, fishing season had a significant impact on the slaughter yield and fatty acid profile of pike fillets and, consequently, on the nutritional value of this species for human consumers. The meat of fish that had spawned had significantly lower contents of PUFA, especially of EPA and DHA, which meant that it was a poorer source of these valuable fatty acids. In this paper we have compared only one fish size group (BW of approximately $0.5 \mathrm{~kg}$ ), which means that this study can be accused of not being representational. We also examined larger fish that had spawned (BW of approximately $1.5 \mathrm{~kg}$ ), and they also had low levels of EPA and DHA at 1.4 and 3.9\% tFA, while the n-3/n-6 ratio was 0.76 (Z. Zakęś et al., unpublished data). 
Acknowledgments. This paper was written as part of statutory project no. S-028 of the Inland Fisheries Institute in Olsztyn and research program no. 528-0704-0806 of the University of Warmia and Mazury. Permission to perform experiments on animals was granted by Local Ethics Committee Resolution no. $24 / 2011$.

Author contributions. Z.Z. designed the research, R.P.-F., M.S., M.M.-K., B.J., and Z.Z. performed the research, Z.Z., M.S., R.P.-F., M.M.-K., and B.J. analyzed the data, Z.Z. wrote the paper.

\section{References}

Folch H., Less M., Stanley H.A. 1957 - A simple method for isolation and purification of total lipids from animal tissues - J. Biol. Chem. 226: 497-499.

Jankowska B., Zakęś Z., Żmijewski T., Szczepkowski M. 2003 - Fatty acid profile and meat utility of wild and cultured zander, Sander lucioperca (L) - EJPAU 6(1), http://www.ejpau.media.pl/volume6/issue1/fisheries/art-02.html.

Jankowska B., Zakęś Z., Żmijewski T., Szczepkowski M. 2008 - Fatty acid composition of wild and cultured northern pike (Esox lucius) - J. Appl. Ichthyol. 24: 196-201.
Jobling M. 2001 - Nutrient partitioning and the influence of feed composition on body composition - In: Food intake in fish (Eds) D. Houlihan, T. Boujard, M. Jobling. Blackwell Sciences Ltd, Oxford, UK: 354-375.

Luzzana U., Serrini G., Moretti V.M., Grimaldi P., Paleari M.A., Valfré F. 1996 - Seasonal variations in fat content and fatty acid composition of male and female coregonid 'bondella' from Lake Maggiore and landlocked shad from Lake Como (Northern Italy) - J. Fish Biol. 48: 352-366.

Peisker K. 1964 - Rapid semi-micro method for extraction of methyl esters from triglycerides using chloroform, methanol, sulphuric acid - J. Am. Oil Chem. Soc. 11: 87-90.

Schwalme K., Mackay W.C., Clandinin M.T. 1993 - Seasonal dynamics of fatty acids composition in female northern pike (Esox lucius L.) - J. Comp. Physiol. 163B: 277-287.

Shirai N., Suzuki H., Tokairin S., Ehara H., Wada S. 2002 Dietary and seasonal effects on the dorsal meat lipid composition of Japanese (Silurus asotus) and Thai catfish (Clarias macrocephalus and hybrid Clarias macrocephalus and Clarias galipinus) - Comp. Biochem. Physiol. 132A: 609-619.

Shirai N., Suzuki H., Tokairin S., Wada S. 2001 - Spawning and season affect lipid content and fatty acid composition of ovary and liver in Japanese catfish (Silurus asotus) Comp. Biochem. Physiol. 129B: 185-195.

Sushchik N.N., Gladyshev M.A., Kalachova G.S. 2007 - Seasonal dynamics of fatty acid content of a common food fish from the Yenisei river, Siberian grayling, Thymallus arcticus - Food Chem. 104: 1353-1358. 